\title{
ERYTHRODERMA- CLINICOPATHOLOGICAL CORRELATION IN NORTH BENGAL POPULATION
}

\author{
Biswajit Haldar', Sutapa Chaudhuri², Biswajit Datta ${ }^{3}$, Amit Kumar Adhikari $^{4}$, Aditya Kumar Tewari ${ }^{5}$, Suman Biswas 6 , Subrata Basu ${ }^{7}$, \\ Rajasree Chakraborty ${ }^{8}$ \\ ${ }_{1}^{1}$ Associate Professor, Department of Pathology, North Bengal Medical College, Darjeeling, West Bengal, India. \\ 2Postgraduate Trainee, Department of Pathology, North Bengal Medical College, Darjeeling, West Bengal, India. \\ 3 Professor and HOD, Department of Urology, North Bengal Medical College, Darjeeling, West Bengal, India. \\ ${ }^{4}$ Assistant Professor, Department of Medicine, Raiganj Medical College, Uttar Dinajpur, West Bengal India. \\ ${ }^{5}$ Radiologist, Department of Radiology, 3Gen Diagnostics (A Unit of North Bengal Healthcare Pvt. Ltd.), Darjeeling, West Bengal, India. \\ ${ }^{6}$ Postgraduate Trainee, Department of Anaesthesiology, North Bengal Medical College, Darjeeling, West Bengal, India. \\ ${ }^{7}$ Assistant Professor, Department of Cardiology, North Bengal Medical College, Darjeeling, West Bengal, India. \\ ${ }^{8}$ Demonstrator, Department of Pathology, North Bengal Medical College, Darjeeling, West Bengal, India.
} ABSTRACT

\section{BACKGROUND}

Erythroderma or exfoliative dermatitis is an inflammatory disorder, it covers $>90 \%$ of the body surface. Hebra proposed it first in 1868. Pre-existing dermatoses comprised majority of cases and these include psoriasis, spongiotic dermatoses, pityriasis rubra pilaris, lichen planus, pemphigus foliaceus etc. Erythroderma is a common clinical presentation of different diseases in this region. Aim- Erythroderma is a serious disease. Histopathological confirmation of causes is urgently required to optimise the therapy.

\section{MATERIALS AND METHODS}

Clinically diagnosed 22 cases of erythroderma who presented to NBMC and H between December 2016 and July 2017 were evaluated and correlation of clinical diagnosis with histopathological features was studied. Results were then analysed.

\section{RESULTS}

Males were affected more than females and chronic spongiotic dermatitis was the most common cause. Erythroderma secondary to malignancy was not observed in this study. Majority (91\%) of erythroderma cases clinically present as a chronic disease and the most common presenting feature was itching (77.27\%). Overall prognosis was good in our study with drug-induced cases.

\section{CONCLUSION}

Erythroderma secondary to pre-existing dermatoses is the major cause with insidious onset and geographic variation.

\section{KEY WORDS}

Erythroderma, Clinicopathological Correlation, Histopathology.

HOW TO CITE THIS ARTICLE: Haldar B, Chaudhuri S, Datta B, et al. Erythroderma- clinicopathological correlation in North Bengal population. J. Evolution Med. Dent. Sci. 2018;7(49):5257-5263, DOI: 10.14260/jemds/2018/1167

\section{BACKGROUND}

Erythroderma is characterised by generalised erythema and scales. It is often associated with fever and haemodynamic and metabolic derangements leading to systemic manifestations. Hebra proposed it first in 1868 as an inflammatory disorder, in which erythema and desquamation occurs in a generalised distribution covering $>90 \%$ of the body surface area. ${ }^{1-4}$

Increased turnover of epidermis in Erythroderma leads to increased rate of mitosis and decreased cell maturation time in epidermis. Loss of epidermal cells leads to severe scaling and shedding.

The eruption is non-specific and may be caused by a variety of underlying conditions. ${ }^{5}$ Incidence is 1 to 2 patients per 1 lac population suffering from erythroderma. ${ }^{6}$ In India incidence is 35 per 1 lac population suffering from skin

'Financial or Other Competing Interest': None.

Submission 05-11-2018, Peer Review 17-11-2018,

Acceptance 20-11-2018, Published 03-12-2018.

Corresponding Author:

Dr. Biswajit Haldar,

A-10/15, Uttorayon Matigara,

Siliguri, Darjeeling-734010

West Bengal, India.

E-mail: biswajitpath@gmail.com

DOI: $10.14260 /$ jemds/2018/1167 problems. ${ }^{7}$ There is male preponderance of disease with age of onset being related to primary aetiology.

Drug reactions, haematological malignancy, especially cutaneous T-cell lymphoma can cause erythroderma without any pre-existing dermatoses. It develops in normal skin (Primary erythroderma). Pre-existing dermatoses such as eczema, psoriasis, pityriasis rubra pilaris, lichen planus, pemphigus foliaceus etc. are the frequent causes of erythroderma (Secondary causes). Psoriasis is the most common cause among pre-existing dermatoses. Aetiological diagnosis by histopathology is possible only in $40 \%$ of cases. Atopic dermatitis, intake of drugs overlooked by the patient, pre-lymphomatous eruptions and occult malignancies are the four common causes of idiopathic erythroderma. 8,9

In one study $74.4 \%$ cases were associated with preexisting dermatoses, $14.6 \%$ were idiopathic and $5.5 \%$ were related to drugs and malignancy. 10

\section{Rationale of the Study}

Erythroderma is a serious disease and common clinical presentation of different dermatoses in this region. Histopathological confirmation of underlying causes is urgently required to optimise the therapy.

\footnotetext{
Aims and Objectives

1. To find out the causes of erythroderma.

2. Morphological variation of erythroderma.
} 


\section{MATERIALS AND METHODS}

22 patients attending OPD and clinically diagnosed as erythroderma were evaluated. Skin punch biopsy were done on 22 patients after a proper informed consent. Histopathological findings of the skin biopsy were recorded. Correlation of clinical diagnosis with histopathological findings were studied.

Study Type and Design- Descriptive study.

Study Place- NBMC and $\mathrm{H}$.

Time Period- December 2016 to July 2017.

Sample Size- 22 patients.

\section{Inclusion Criteria of Patients}

All clinically diagnosed cases of erythroderma attending OPD/ Medicine Dept.

\section{Exclusion Criteria}

1. Debilitated patients.

2. Patients not giving consent.

3. Bleeding disorder.

4. Immunocompromised.

\section{RESULTS}

\section{Age Wise Distribution}

Range of erythroderma cases - 16 to 60 years.

Mean age is 43.08 years. Most common age of presentation in chronic spongiotic dermatitis is in between 50 and 60 yrs. (40\%). Most common age of presentation in psoriasis is also between 50 and 60 yrs. (42.8\%).

\begin{tabular}{|c|c|c|c|c|c|c|}
\hline & 오 & ஜి & 古 & $\begin{array}{l}\text { 우 } \\
\text { ํㅜㅁ }\end{array}$ & $\begin{array}{l}\text { lo } \\
\text { ò }\end{array}$ & 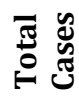 \\
\hline CSD & & 2 & 1 & 3 & 4 & 10 \\
\hline Psoriasis & 1 & & 1 & 2 & 3 & 7 \\
\hline Lichen planus & & 1 & & 1 & & 2 \\
\hline Pemphigus foliaceus & & & & & 1 & 1 \\
\hline Non-specific dermatitis & & & & 1 & 1 & 2 \\
\hline \multicolumn{7}{|c|}{ Table 1. Age Wise Distribution } \\
\hline
\end{tabular}

Most of the cases has chronic insidious onset. Only 2 cases present with acute presentation (9\%). In previous studies chronic onset disease was of $85 \%$, while our study showed chronic onset of $91 \%$. According to operational definition, patient suffering from disease for more than 6 weeks was considered as chronic erythroderma.

\section{Incidence Distribution of Erythroderma Cases}

Chronic spongiotic dermatitis is the commonest cause of erythroderma in our study and second common cause is psoriasis. Definitive diagnosis could not be done in 2 cases. They were termed as chronic non-specific dermatitis.

\begin{tabular}{|c|c|c|}
\hline & Total Cases & Percentage of Cases \\
\hline CSD & 10 & $45.45 \%$ \\
\hline Psoriasis & 7 & $31.8 \%$ \\
\hline Lichen planus & 2 & $9 \%$ \\
\hline Pemphigus foliaceus & 1 & $4.5 \%$ \\
\hline Non-specific dermatitis & 2 & $9 \%$ \\
\hline \multicolumn{2}{|c|}{ Table 2. Incidence distribution of Erythroderma Cases } \\
\hline
\end{tabular}

\section{Gender Distribution}

Males were suffering more than females and the ratio of male-to-female was 1.44: 1 . In psoriasis ratio of male-tofemale was 1.33: 1 , while in chronic spongiotic dermatitis ratio was 1.66: 1 .

\begin{tabular}{|c|c|c|}
\hline & Male & Female \\
\hline CSD & 6 & 4 \\
\hline Psoriasis & 4 & 3 \\
\hline Lichen planus & 1 & 1 \\
\hline Pemphigus foliaceus & 1 & \\
\hline Non-specific dermatitis & 1 & 1 \\
\hline Total & 13 & 9 \\
\hline \multicolumn{3}{|c|}{ Table 3. Gender Distribution } \\
\hline
\end{tabular}

\section{Clinical Presentation}

Erythema was seen in all erythroderma patients, whereas scaling and itching was found in most of the cases. Scaling was found in $(77.27 \%)$ cases and itching was present in $(77.27 \%)$ cases.

*CSD- Chronic spongiotic dermatitis.

\begin{tabular}{|c|c|c|c|c|c|c|c|c|}
\hline & Scaling & Oozing & Itching & $\begin{array}{c}\text { Nail } \\
\text { Changes }\end{array}$ & $\begin{array}{c}\text { Mucosal } \\
\text { Changes }\end{array}$ & $\begin{array}{c}\text { Hair } \\
\text { Changes }\end{array}$ & $\begin{array}{c}\text { Skin } \\
\text { Manifestations }\end{array}$ & $\begin{array}{c}\text { Systemic } \\
\text { Manifestations }\end{array}$ \\
\hline CSD & 7 & 5 & 8 & 3 & 2 & 1 & & 7 \\
\hline Psoriasis & 7 & 3 & 5 & 5 & 2 & 3 & Bleeding points (Auspitz' sign) & 6 \\
\hline Lichen planus & 1 & & 2 & 0 & 1 & & Flat topped violaceous papules & \\
\hline $\begin{array}{c}\text { Pemphigus } \\
\text { foliaceus }\end{array}$ & 1 & 1 & 0 & 0 & 0 & 0 & Flaccid bulla & 1 \\
\hline $\begin{array}{c}\text { Non-specific } \\
\text { dermatitis }\end{array}$ & 1 & 2 & 2 & 0 & 0 & 1 & & 1 \\
\hline \multicolumn{8}{|c|}{ Table 4. Clinical Presentation } \\
\hline
\end{tabular}

Systemic manifestation like fever, tachycardia, pedal oedema and anaemia and weight loss was found in $68.18 \%$ cases. Most of the nail changes were due to psoriasis (70\%). Among the cases of chronic spongiotic dermatitis, 2 cases had the history of intake of antiepileptic (Carbamazepine) and NSAIDs. One case gave the history of exposure to detergent (Soap during washing). 


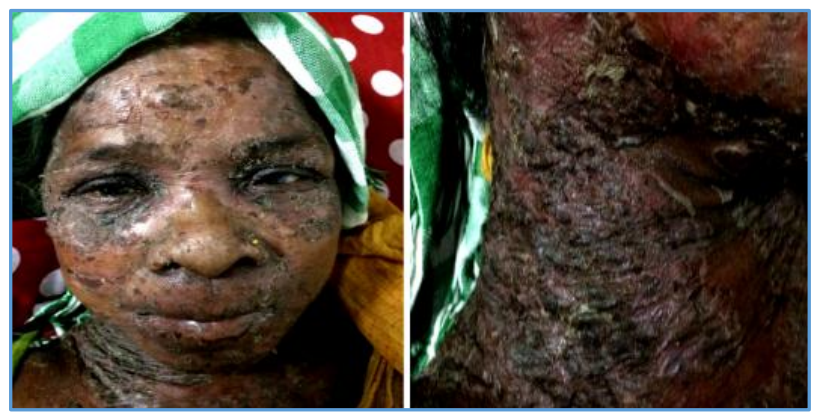

Figure 1. Erythroderma with Crust

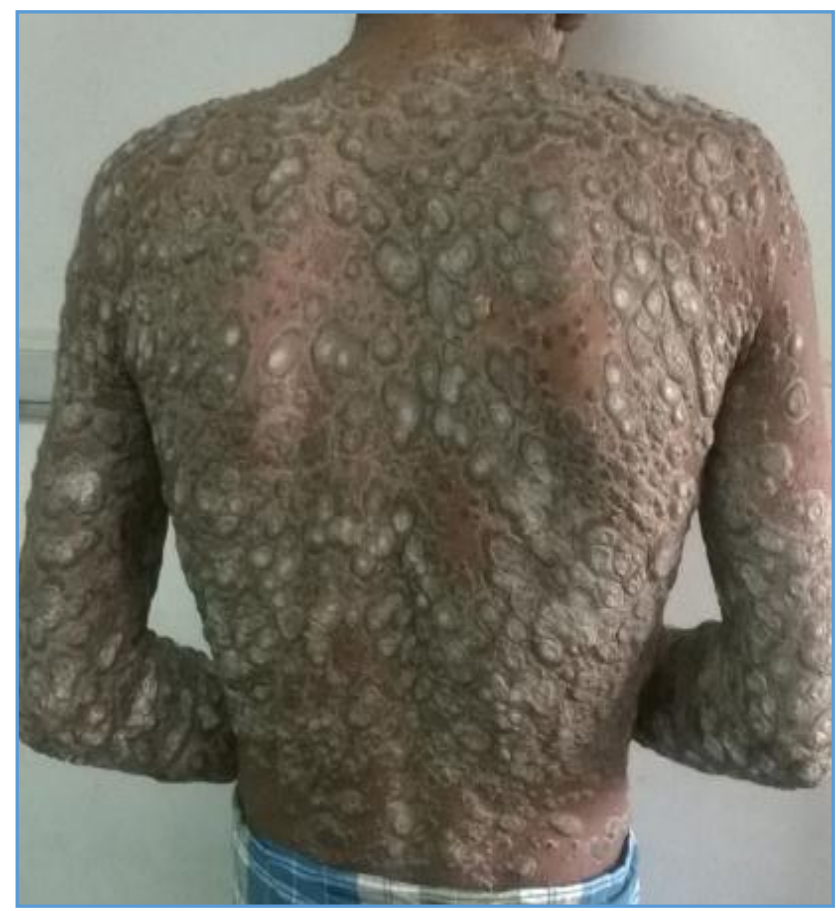

Figure 2. Psoriasis, clinically diagnosed as Erythroderma

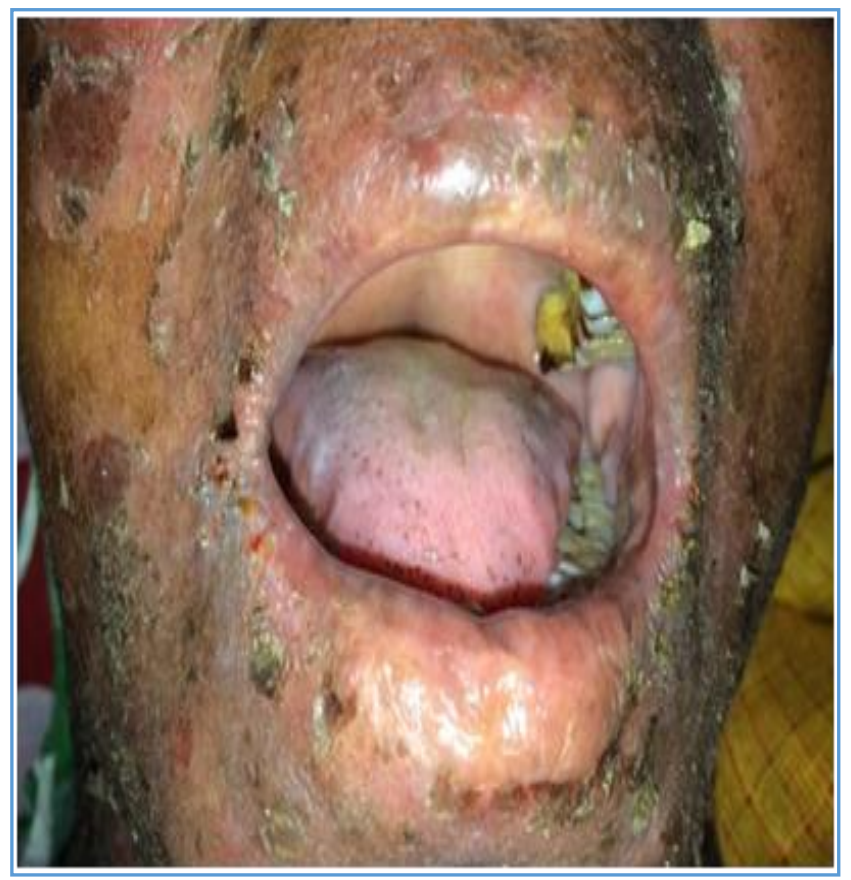

Figure 3. Erythroderma with Scaling and Oozing

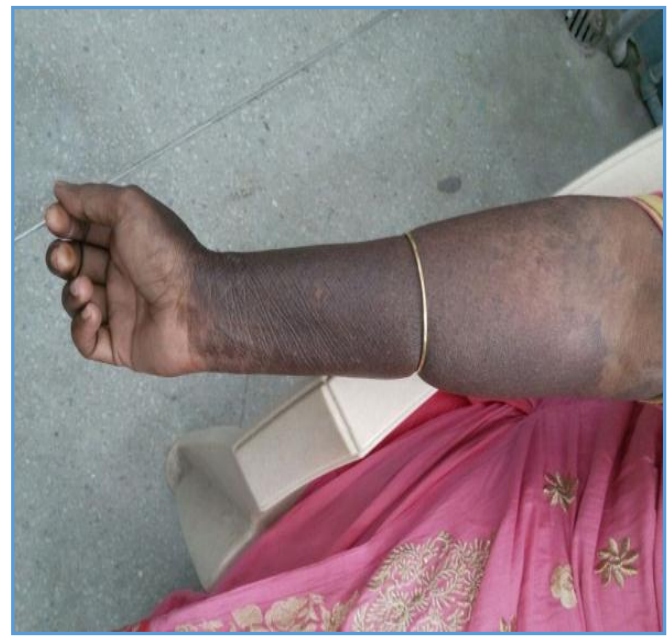

Figure 4. Clinically present as Lichen Planus

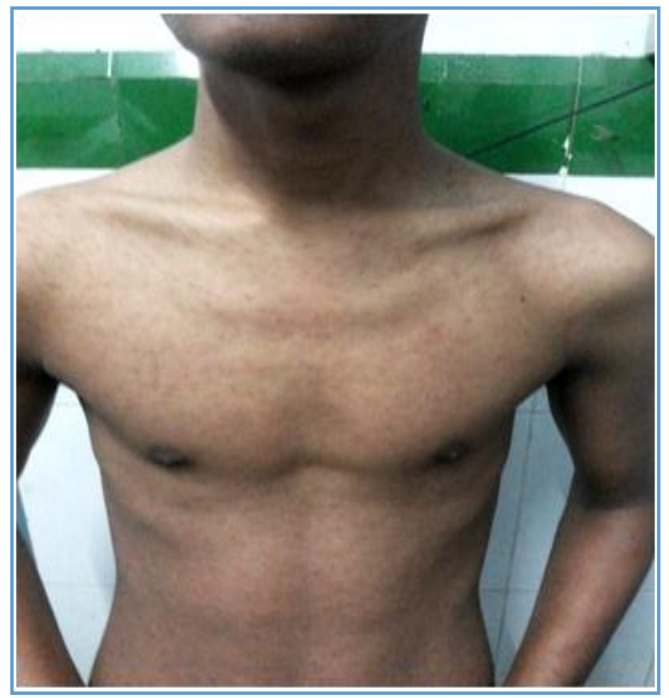

Figure 5. Carbamazepine-Induced Erythema

\section{Histological Findings}

All (22 cases) punch biopsy specimens were processed, and routine Haematoxylin and Eosin staining were done to find out underlying aetiology. Histopathological observations were recorded. Definitive diagnosis were done in 20 (90\%) cases. Remaining 2 cases with definitive diagnosis could not be done and termed as chronic non-specific dermatitis.

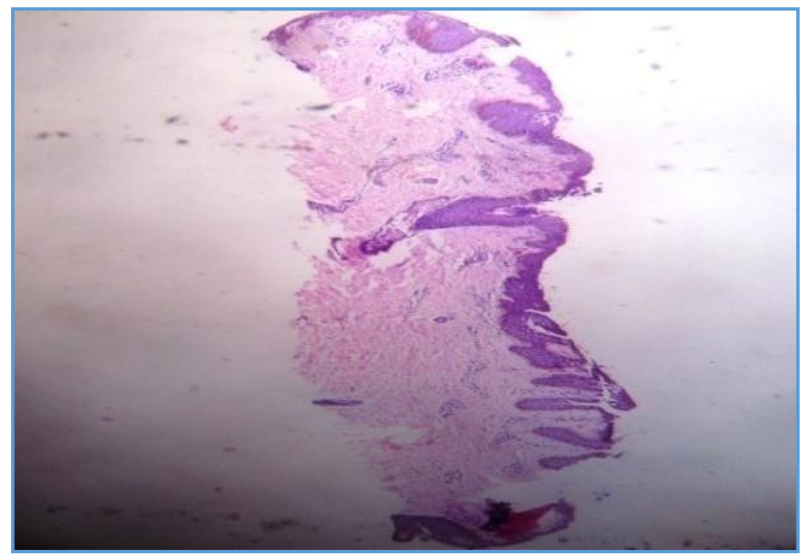

Figure 6. Photomicrograph of Pemphigus Foliaceus (10x) 


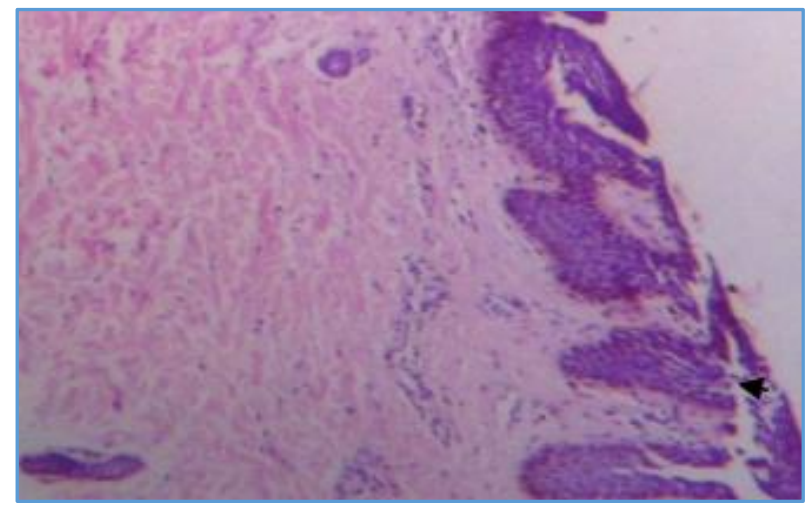

Figure 7. Photomicrograph of Pemphigus Foliaceus (40x), Subcorneal Blister (Arrow Head)

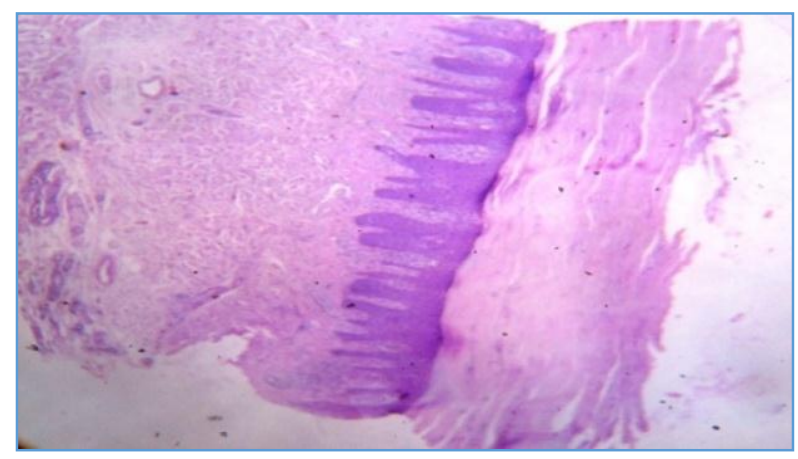

Figure 8. Photomicrograph of Psoriasis (10x)

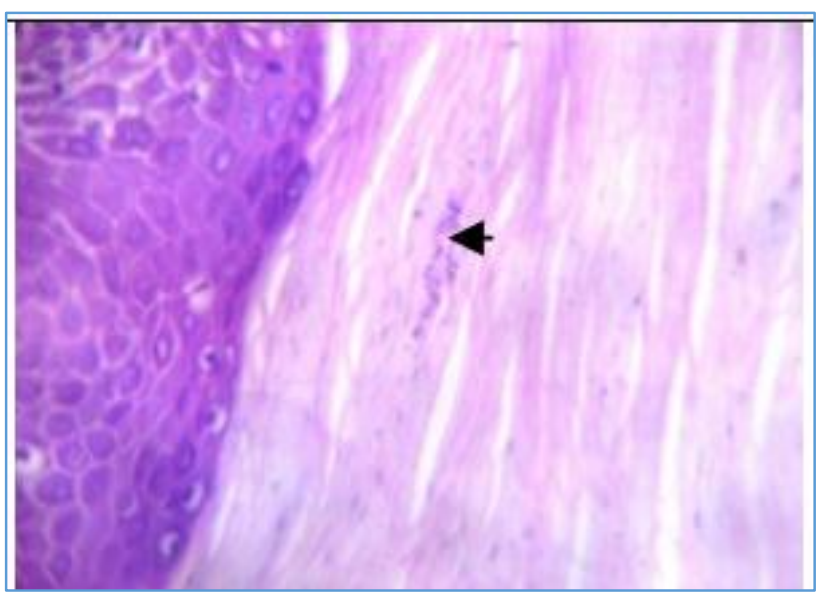

Figure 9. Photomicrograph of Psoriasis (40x), Arrow Head shows Munro Abscess

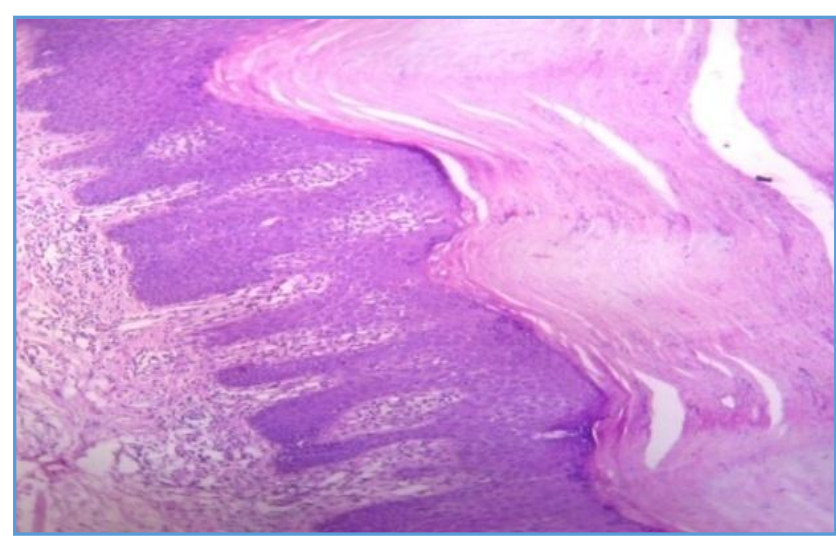

Figure 10. Spongiotic Dermatitis (40x) clinically presents as Erythroderma

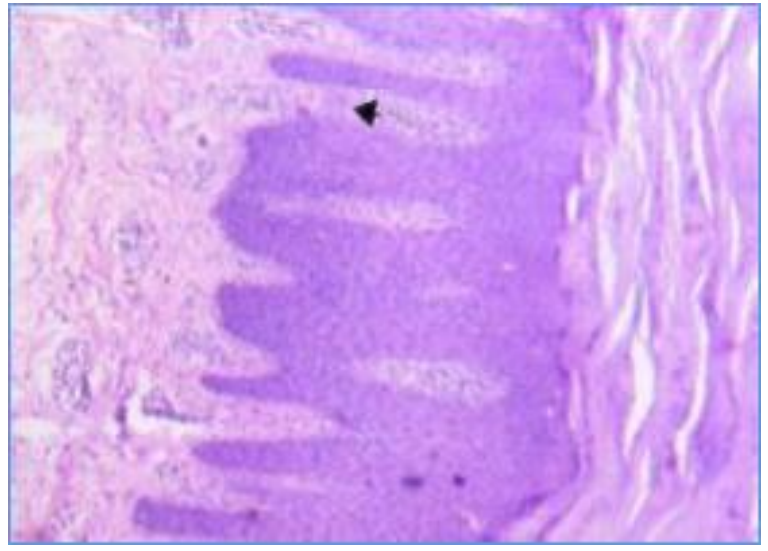

Figure 11. Lichen Simplex Chronicus, arrow head shows Vertically Oriented Collagen

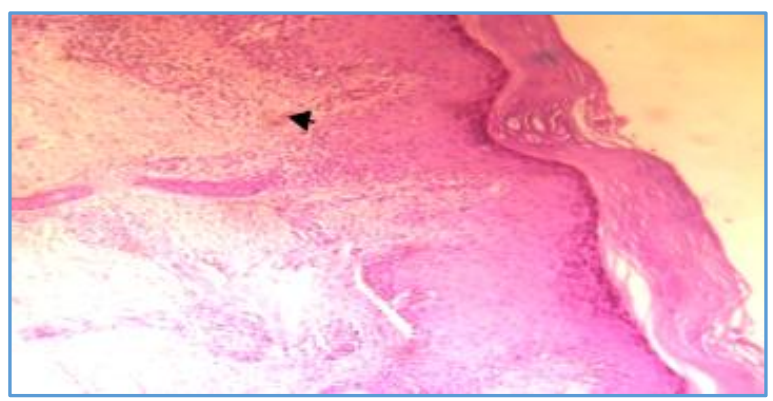

Figure 12. Lichen Planus (40x), Irregular Acanthosis and Lymphocytes Infiltration Clinical (Arrow Head)

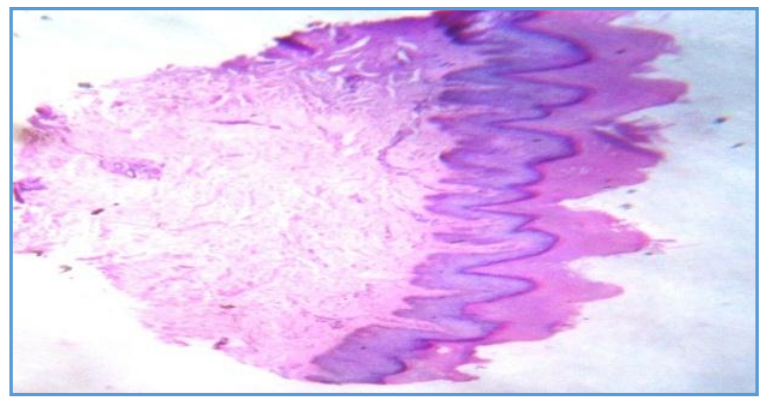

Figure 13. Chronic Non-Specific Dermatitis in Carbamazepine-Induced Erythema

\begin{tabular}{|c|c|c|c|c|c|c|c|c|c|c|c|}
\hline & 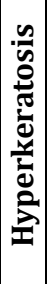 & 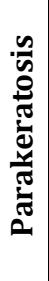 & 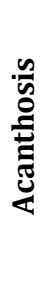 & 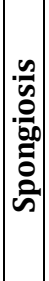 & 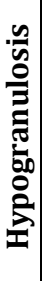 & 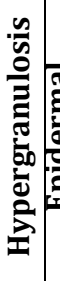 & 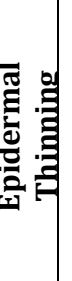 & 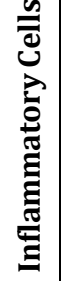 & 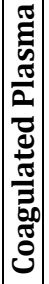 & 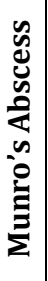 & 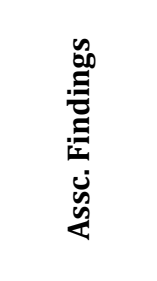 \\
\hline CSD & 9 & 4 & 6 & 7 & & 7 & 2 & 7 & 3 & & $\begin{array}{c}\text { Papillary } \\
\text { dermal } \\
\text { fibrosis }\end{array}$ \\
\hline Psoriasis & 3 & 6 & 7 & 4 & 6 & & 6 & 6 & & 3 & $\begin{array}{l}\text { Elongated } \\
\text { rete ridges } \\
\text { and dilated } \\
\text { capillaries }\end{array}$ \\
\hline $\begin{array}{l}\text { Lichen } \\
\text { planus }\end{array}$ & 1 & 1 & 1 & 1 & 0 & 1 & 0 & 1 & 0 & 0 & $\begin{array}{l}\text { Saw tooth } \\
\text { rete ridges }\end{array}$ \\
\hline $\begin{array}{c}\text { Pemphigus } \\
\text { foliaceus }\end{array}$ & 1 & 0 & 1 & 1 & 0 & & 0 & 1 & & 0 & $\begin{array}{c}\text { Subcorneal } \\
\text { blister }\end{array}$ \\
\hline $\begin{array}{c}\text { Non- } \\
\text { specific- } \\
\text { dermatitis }\end{array}$ & 3 & 0 & 2 & 0 & 0 & 2 & 0 & 3 & 2 & 0 & \\
\hline
\end{tabular}




\begin{tabular}{|c|c|c|}
\hline Hyperkeratosis & 17out of 22 & $77.27 \%$ \\
\hline Acanthosis & 18 out of 22 & $81.81 \%$ \\
\hline Parakeratosis & 11 out of 22 & $50 \%$ \\
\hline Spongiosis & 13 out of 22 & $59.09 \%$ \\
\hline Hypogranulosis & 6 out of 22 & $27.27 \%$ \\
\hline Hypergranulosis & 10 out of 22 & $45.45 \%$ \\
\hline Inflammatory cell & 18 out of 22 & $81.81 \%$ \\
\hline Munro's abscess & 3 out of 22 & $13.6 \%$ \\
\hline Epidermal thinning & 8 out of 22 & $36.36 \%$ \\
\hline \multicolumn{2}{|c|}{ Table 6. Analysis of Histological Features of different } \\
Diseases \\
\hline
\end{tabular}

Most of the cases presented with histological features of acanthosis followed by hyperkeratosis. In CSD spongiosis was present in $70 \%$ cases, but in psoriasis spongiosis was found in $57.14 \%$ cases. Epidermal thinning was present in $85.7 \%$ cases of psoriasis, while $20 \%$ cases in CSD. Coagulated plasma keratin was observed in CSD cases. In 3 out of 7 cases of psoriasis had Munro's abscess $(42.85 \%)$. Saw tooth rete ridges was found in Lichen planus. Inflammatory cell was found in most of the cases. Subcorneal blister was found in pemphigus foliaceus.

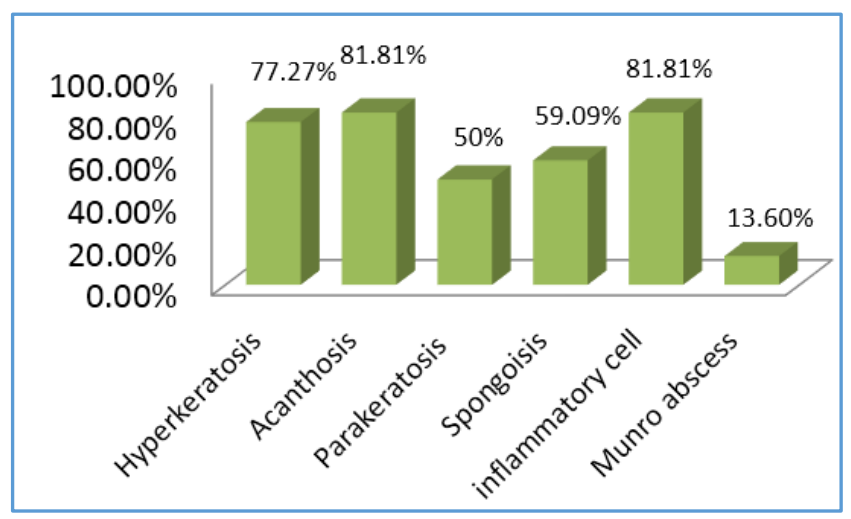

Figure 14. Histopathological Findings of Erythroderma

\begin{tabular}{|c|c|c|c|c|c|}
\hline & $\begin{array}{l}\text { Erythroderma: a } \\
\text { Clinico-aetiologic } \\
\text { study of } 90 \text { cases. } \\
\text { Pal S1, Haroon TS. }\end{array}$ & $\begin{array}{c}\text { Erythroderma: A Clinical } \\
\text { study of } 97 \text { cases } \\
\text { Maryam Akhyani, } 1 \text { Zahra } \\
\text { S Ghodsi, } 1 \text { Siavash Toosi, } \\
1 \text { and Hossein Dabbaghia }\end{array}$ & \begin{tabular}{|} 
Clinico- \\
aetiopathological Study \\
of Erythroderma. \\
Chetana P,1 \\
Krishnakanth $\mathrm{M}^{2}$ Sudha \\
R,3 Gayathri R,4 \\
Murugan S 3 and \\
Mahalakshmi V.11
\end{tabular} & $\begin{array}{c}\text { A Study of } \\
\text { correlation } \\
\text { between Clinical } \\
\text { and } \\
\text { Histopathological } \\
\text { Findings of } \\
\text { Erythroderma in } \\
\text { North Bengal } \\
\text { Population }\end{array}$ & $\begin{array}{c}\text { Present } \\
\text { Study }\end{array}$ \\
\hline \multicolumn{6}{|c|}{ Causes } \\
\hline CSD & 12.2 & 20.2 & 8.76 & 34 & 45.45 \\
\hline Psoriasis & 37.8 & 27.8 & 43.8 & 21.8 & 31.18 \\
\hline Lichen planus & & 1.5 & & & 4.5 \\
\hline Pemphigus foliaceus & 5.6 & 1 & 3.5 & 0 & 4.5 \\
\hline Non-specific dermatitis & 14.6 & 7.2 & 3.5 & 40.63 & 13.6 \\
\hline \multicolumn{6}{|c|}{ Clinical Presentation } \\
\hline Male: Female ratio & $2.8: 1$ & $1.85: 1$ & $1.48: 1$ & $1.5: 1$ & $1.44: 1$ \\
\hline Scaling and itching & & $97.5 \%$ & $100 \%$ & $68.7 \%$ & 77.27 \\
\hline Nail changes & $80 \%$ & & $75.43 \%$ & 21.8 & 36.6 \\
\hline Systemic complication & & $72 \%$ & $57.8 \%$ & $46.8 \%$ & 45.45 \\
\hline
\end{tabular}

\begin{tabular}{|c|c|c|c|}
\hline HP Findings & Our Study & $\begin{array}{c}\text { Previous } \\
\text { Study of North } \\
\text { Bengal }\end{array}$ \\
\hline Hyperkeratosis & 17 out of 22 & $77.27 \%$ & $53.12 \%$ \\
\hline Acanthosis & 18 out of 22 & $81.81 \%$ & $87.7 \%$ \\
\hline Parakeratosis & 11 out of 22 & $50 \%$ & $62.5 \%$ \\
\hline Spongiosis & 13 out of 22 & $59.09 \%$ & $31.25 \%$ \\
\hline $\begin{array}{c}\text { Inflammatory } \\
\text { cell }\end{array}$ & 18 out of 22 & $81.81 \%$ & $62.5 \%$ \\
\hline \multicolumn{3}{|c|}{ Table 8. Comparison between Previous } \\
Study in this Region \\
\hline
\end{tabular}

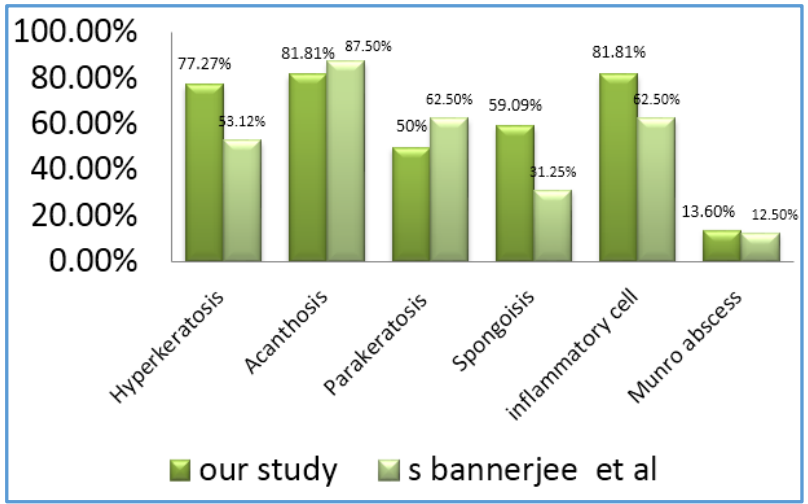

Figure 15. Histopathological Comparison, studies from North Bengal 


\section{DISCUSSION}

A total number of 22 cases clinically diagnosed as erythroderma from December 2016 to July 2017, attending the Department of Dermatology were taken up for the clinicohistopathological evaluation.

In this study, it was seen that erythroderma was more common in males and the male-to-female ratio was 1.44: 1 . Earlier studies also demonstrated the same result, which was shown in table. Male-female ratio was 1.66: 1 in a study done previously in North Bengal. ${ }^{12}$

Psoriasis (31.8\%) was the second common cause of erythroderma found in the present study, but it was the commonest cause of erythroderma observed in studies conducted by Sehgal et $\mathrm{al}^{7}$ and Pal S Haroon. ${ }^{10}$ Chronic spongiotic dermatitis (45.5\%) was the most common cause of erythroderma found in the present study, since it included all the cases of spongiotic dermatitis irrespective of types. Similar findings was published in Jowker et $\mathrm{al}^{13}$ and they showed subacute and chronic dermatitis was the most common histopathological finding (35.18\%) followed by drug reaction $(16.66 \%)$ and psoriasis (14.81\%). Subcategorisation of spongiotic dermatitis was not done in this present study.

Pemphigus foliaceus was the underlying cause of erythroderma in $4.5 \%$ cases in the present study. This is corroborated well with previous 2 studies. Erythroderma due to underlying pemphigus foliaceus was seen in 3.5\% of patients in study done by Chetana et al,11 in King Le et al ${ }^{14}$ and Abrahams et al. ${ }^{15}$ This dermatosis did not exceed $2 \%$. Study conducted by Pal S et al, ${ }^{10}$ the frequency of pemphigus foliaceus was 5.6 , whereas $6.25 \%$ in a study conducted by Rym et al. 16

Erythroderma secondary to malignancy was not found in the present study. Similar findings were observed in a study conducted by Sehgal et al 7 and study done by Chetana et al. ${ }^{11}$

In the present study, cause of erythroderma could not be determined in $9.09 \%$ patients as mentioned in different previous studies. ${ }^{10,11,16}$

In our study, no HIV patient was detected as like a study conducted by Akhyani et al, whereas $1.75 \%$ patients were HIV-positive in study conducted by Chetana $\mathrm{P}$ and Krishnakanth M.11

In our study, no case of erythroderma due to malignancy was reported. Cutaneous lymphoma is the most common cause of exfoliative dermatitis, but solid tumour of breast, lung, prostate, colon and thyroid can cause erythroderma.

No remarkable laboratory abnormality was detected in patient's record in our study. This finding was similarly reported by Haroon and Pal. ${ }^{10}$

Presentation of erythroderma may be acute or chronic. Most cases of erythroderma with acute presentation were drug induced.12 In the present study majority (91\%) of erythroderma cases had chronic onset, whereas $9 \%$ cases had acute onset. Clinical features appear six weeks before the presentation is considered as chronic onset, though no standard demarcation. ${ }^{12}$

Most common presenting feature was itching (77.27\%), which was similar in study done on North Bengal population previously (68.7\%). ${ }^{12}$ All patients had erythema and scaling. In our study nail changes was found in $36.36 \%$ cases, but it was only evident in $21.8 \%$ cases in previous study done on North Bengal population. ${ }^{12}$ Systemic complication was found in $45.45 \%$ cases and most are secondary to Psoriasis and this correlates well with the previous study. Nail changes was mostly found associated with psoriasis $(71.4 \%)$, but it was found in $63.6 \%$ cases in previous study of North Bengal. ${ }^{12}$

In our study, acanthosis was the most common histopathological finding (81.81\%) similar to previous study done in North Bengal $87.5 \%$ cases followed by mixed cellular infiltrates in dermis $81.81 \%$ cases. Hyperkeratosis was seen in $77.27 \%$ cases but in previous study it was $53.12 \%$ cases, spongiosis in $59.09 \%$ cases but it was only $31.25 \%$ in previous study.

Drug-induced cases responded very well to treatment. No death recorded. Overall prognoses was good in our study. This study outlines that some important features of erythroderma may show geographic variations.

\section{We Recognised Two Limitations of Our Study}

1. Small sample size. So true incidence of erythroderma in this region could not be determined.

2. Erythroderma due to malignancy and its presentation could not be analysed, because no malignant case was found. Large scale study with long follow-up is required to overcome above-mentioned limitations.

\section{CONCLUSION}

Majority of erythroderma cases were due to pre-existing dermatosis. Chronic spongiotic dermatitis is the most common cause. Incidence of idiopathic erythroderma was very low in our study. Itching is the commonest presentation besides erythema and scaling. Histopathologically, acanthosis was a remarkable change. Males were suffering more than females with insidious onset. This study outlines the underlying aetiologic factors of erythroderma in this geographic region.

\section{REFERENCES}

[1] Burton JL. Erythroderma: Rook, Wilkinson, Ebling Textbook of Dermatology. In: Champion RH, Burton JL, Ebling FJ, eds. $5^{\text {th }}$ edn. Vol. 1. United States: Oxford Blackwell Scientific Publications 1992: p. 584-8.

[2] Nicolis GD, Helwig EB. Exfoliative dermatitis: a clinicopathologic study of 135 cases. Arch Dermatol 1973;108(6):788-97.

[3] Herman LE, Kurban AK. Erythroderma as a manifestation of AIDS related complex. J Am Acad Dermatol 1987;17(3):507-8.

[4] Shelley WB, Shelley ED. Advanced dermatologic therapy. Philadelphia: WB Saunders 1987: p. 185-9.

[5] Wu H, Schapiro B, Harrist TJ. Non-infectious vesiculobullous and vesiculopustular diseases. In: Elder D, Elenitsas R, Johnson BL, et al. eds. Lever's histopathology of skin. 9th edn. Philadelphia: Lippincott Williams \& Wilkins 2005: p. 243-29.

[6] Sigurdsson V, Steegmans PH, van Vloten WA. The incidence of erythroderma: a survey among all dermatologists in the Netherlands. J Am Acad Dermatol 2001;45(5):675-8.

[7] Shegal VN, Srivastava G. Exfoliative dermatitis: a prospective study of 80 patients. Dermatologica 1986;173(6):278-84. 
[8] Botella-Estrada R, Sanmartin O, Oliver V, et al. Erythroderma: a clinicopathological study of 56 cases. Arch Dermatol 1994;130(12):1503-7.

[9] Burton JL, Holden CA. Eczema, lichenification and prurigo. In: Champion RH, Burton JL, Burns DA, et al. eds. Text book of Dermatology. Vol. 1. $6^{\text {th }}$ edn. Oxford: Blackwell Scientific Publications 1998: p. 673-8.

[10] Pal S, Haroon TS. Erythroderma: a clinico-etiologic study of 90 cases. Int J Dermatol 1998;37(2):104-7.

[11] Chetana P, Krishnakanth M, Sudha R, et al. Clinicoaetiopathological study of erythroderma. JEMDS 2015;4(88):15360-6.

[12] Banerjee S, Ghosh S, Mandal RK. A study of correlation between clinical and histopathological findings of erythroderma in North Bengal population. Indian J of Dermatology 2015;60(6):549-55.
[13] Jowker F, Aslani FS, Shafiee M. Erythroderma: a clinicopathological study of 102 cases. J Pak Assoc Dermatol 2006;16:129-33.

[14] King LE Jr, Dufresne RG Jr, Lovett GL, et al. Erythroderma - review of 82 cases. South Med J 1986;79(10):1210-5.

[15] Abrahams I, McCarthy JT, Saunders SL. One hundred and one cases of exfoliative dermatitis. Arch Dermatol 1963;87(1):96-101.

[16] Rym BM, Mourad M, Bechir Z, et al. Erythroderma in adults: a report of 80 cases. Int J of Dermatol 2005;44(9):731-5. 